\title{
Imagens pedagógicas da comunicação
}

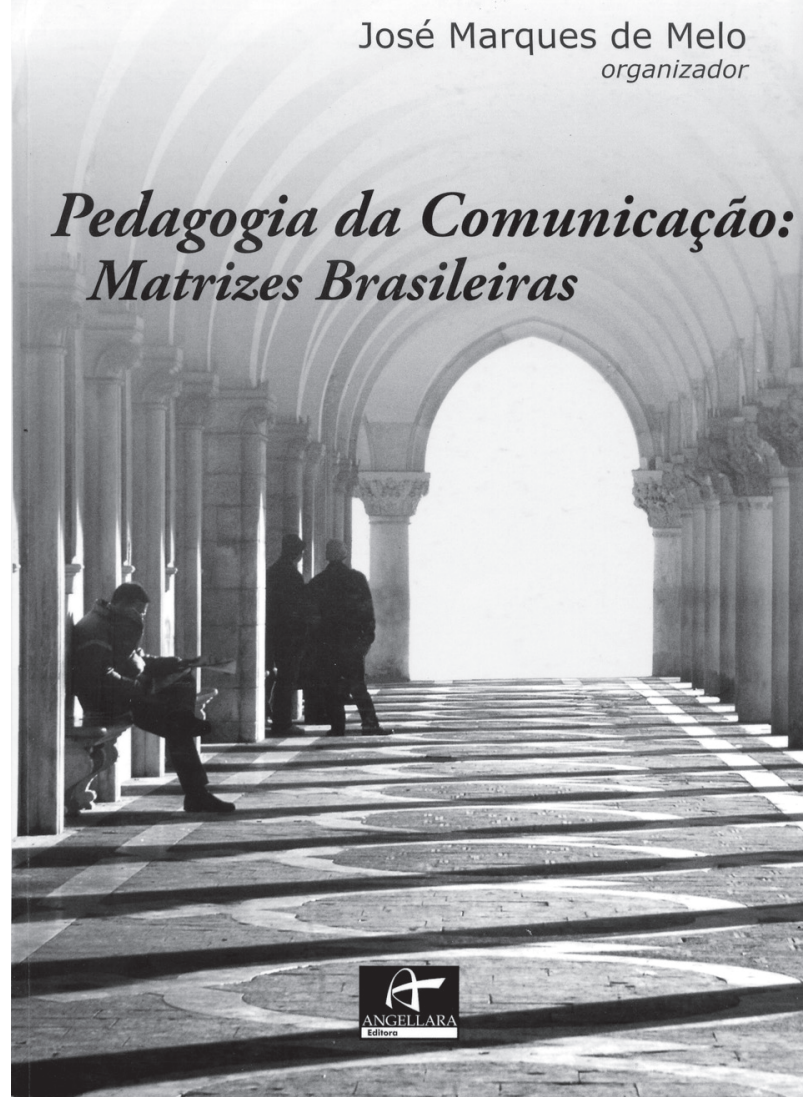

MARQUES DE MELO, J. (org.). Pedagogia da Comunicação: matrizes brasileiras. São Paulo: Angellara, 2006. $370 \mathrm{p}$.

\section{Francisco de Assis UMESP}

E stratégias pedagógicas para o ensino de Comunicação no Brasil têm sido tema constante de discussões no meio acadêmico. No entanto, até 2006, a bibliografia específica do assunto se mostrava um tanto insipiente, tendo sido explorada duas ou três vezes, num período de seis décadas ${ }^{1}$. Como contribuição a esta lacuna, foi lançado, pela Editora Angellara, um volume que aponta aspectos e tendências dessa modalidade educacional: trata-se do livro Pedagogia da Comunicação: matrizes brasileiras, organizado pelo prof. Dr. José Marques de Melo, membro do corpo docente da Universidade Metodista de São Paulo e diretor da Cátedra Unesco/Umesp de Comunicação para o Desenvolvimento Regional.

Coletânea de textos produzidos, em 2004, por mestrandos e doutorandos do PósCom-Metodista ${ }^{2}$, como atividade da disciplina Metodologia do Ensino da Comunicação, somados a artigos elaborados para o $8^{\circ}$ Colóquio Internacional sobre a Escola Latino-Americana de Comunicação (Celacom) e a outros ensaios, a obra se divide, basicamente, em quatro focos, que dão conta das abordagens sobre os pilares das universidades, a contribuição das instituições pioneiras de São Paulo, as revisões propostas por centros de referência e os novos modelos didáticos adotados pelas escolas brasileiras.

O livro chama a atenção pela infinidade de dados estatísticos registrados pelos autores, que desenham um mapa situacional das carreiras em comunicação no Brasil. Entre essas informações, destaca-se o número de cursos de graduação da área oferecidos no país, que, segundo censo realizado em 2001, alcança a margem de 525, entre jornalismo, publicidade, audiovisual (TV, rádio, cinema e vídeo), relações públicas e produção editorial ou cultural.

Outro aspecto relevante e que interessa não só aos professores, como também aos dirigentes das universidades, são as questões levantadas no primeiro capítulo, que tratam de temas como a obrigatoriedade do diploma de jornalismo, as avaliações do MEC, a contribuição das atividades científicas - ilustradas pela descrição das atividades desenvolvidas pelo Grupo Comunicacional de São Bernardo - e a necessidade da extensão universitária como forma de se manter um fecundo diálogo com a sociedade.

As diferentes abordagens se entrelaçam sempre em um ponto-comum: a motivação para compreender as táticas pedagógicas adotadas pelas escolas que se prestam a preparar operários para a indústria midiática. Muito embora cada texto descreva uma experiência singular, todos eles espelham os impasses e as saídas para situações do dia-a-dia na sala de aula, mostrando o que pode dar certo e o que certamente não é uma boa opção.

Relatos de implantação e reorganização de progra- 
mas pedagógicos, grades curriculares, projetos laboratoriais e outras inovações também são uma constante em toda a extensão do volume. A leitura atenta a esses tópicos conduz a uma visão-macro do ensino em comunicação no Brasil, com a possibilidade de comparar diferenças e avaliar as estruturas das nove escolas estudadas ${ }^{3}$.

O conjunto dos capítulos também deixa transparecer uma preocupação levantada pelo professor José Marques de Melo, logo no trecho introdutório: o distanciamento que a academia mantém das urgências e demandas geradas pelo mercado midiático. A idéia do organizador, comungada por vários dos autores, recai sobre a falta de perspectiva de muitas universidades ao elaborarem currículos desconexos com a realidade do lado de fora de seus portões, muitas vezes submissos aos paradigmas das Ciências Sociais, que não são suficientes para preparar os futuros profissionais da área. Como resposta a essa deixa, são apresentadas algumas propostas que podem, ao menos em parte, solucionar os problemas.

Assinam a obra, junto com Marques de Melo, Alexandre Henrique, Backer Ribeiro Fernandes, Bruna Vieira Guimarães, Christiane Macedo, Fabiana Franco, Herbert Rodrigues de Souza, Joaquim Valverde, Jairo Faria Mendes, José Aurélio Chiaradia Pereria, Josias Ricardo Hack, Laércio Arruda, Leninne Guimarães Freitas, Márcia Mercês Martins Sedevitiz, Márcia Perencin Tondato, Maria Rita Teixeira Afonso, Mérli Leal Silva, Missila Loures Cardozo, Nanci Maziero Trevisan, Rosalba Facchinetti, Roseane Arcanjo Araújo, Sandra Guedes, Silma Cortes da Costa Battezzatti, Sônia Maria Gobbo e William Pereira de Araújo.

Pedagogia da Comunicação: matrizes brasileiras é, seguramente, um livro que pode ser utilizado como um confiável manual por jovens professores e como fonte para se repensar as práticas de ensino adotadas por aqueles que já têm cadeira cativa nos cursos de comunicação do País. mfamecos

\section{NOTAS}

1. Embora, no Brasil, a formação de profissionais de comunicação tenha tido início dentro das empresas, tem-se, como marco da educação comunicacional brasileira, a criação da Escola de Jornalismo Cásper Líbero, em 1947.

2. Programa de Pós-graduação em Comunicação Social da Universidade Metodista de São Paulo.

3. Cásper Líbero, ECA-USP, ESPM, FAENAC, PUC, SENAC, UMESP, UNOESC e UPF-RS. 